\title{
IMAGES IN DERMATOLOGY
}

\section{Condylomata Acuminata in Childhood Condilomas Acuminados na Infância} 2020/10/26

Accepted/Aceite 2020/12/05

Published/Publicado $2021 / 03 / 30$

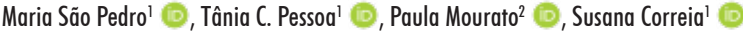 \\ 'Pediatrics, Centro Hospitalar Barreiro-Montijo, Barreiro, Portugal \\ 2Pediatrics, Pediatrics Gastroenterology Unit, Centro Hospitalar Lisboa-Norte, Lisboa, Portugal
}

KEYWORDS - Child; Condylomata Acuminata; Nitric Acid/therapeutic use; Papillomavirus Infections; Zinc/therapeutic.

PALAVRAS-CHAVE - Ácido Nítrico/uso terapêutico; Condilomas Acuminados; Criança; Infecções por Papillomavirus; Zinco/uso terapêutico.

A three-years-old male child was referred for a pediatric consultation due to perianal lesions noted 4 months prior evaluation, associated with constipation. Perianal skin-colored verrucous papules with approximately 1 to $5 \mathrm{~mm}$ diameter were noticed, the most exophytic having a cauliflower-like appearance (Fig. 1). Extension to the anal mucosa was evident (Fig. 2), with no similar lesions observed in other locations. Clinical findings were consistent with condylomata acuminata (anogenital warts). Lesion biopsies confirmed the diagnosis and human papillomavirus (HPV) genotyping identified serotypes 6 and 11 by polymerase chain reaction. Immunodeficiency and other sexually transmitted diseases (human immunodeficiency virus, hepatitis $B$ and $C$ virus, herpes simplex virus and syphilis) were excluded.

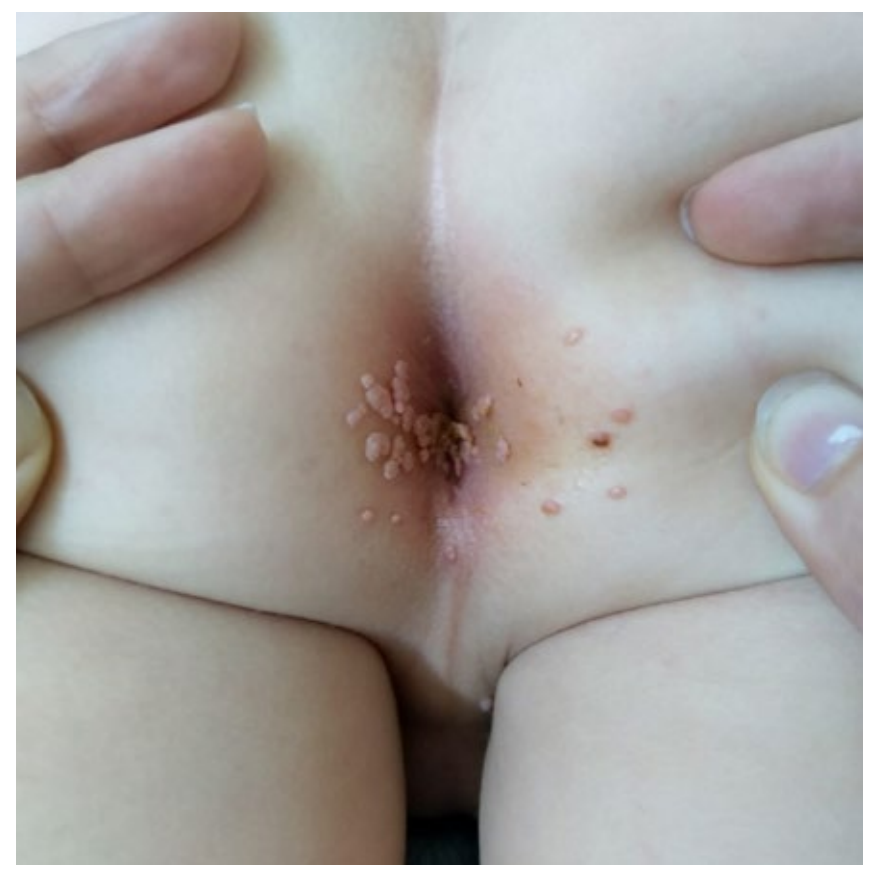

Figure 1 - Extensive perianal skin-colored verrucous papules, some with cauliflower-like appearance, consistent with anogenital warts.

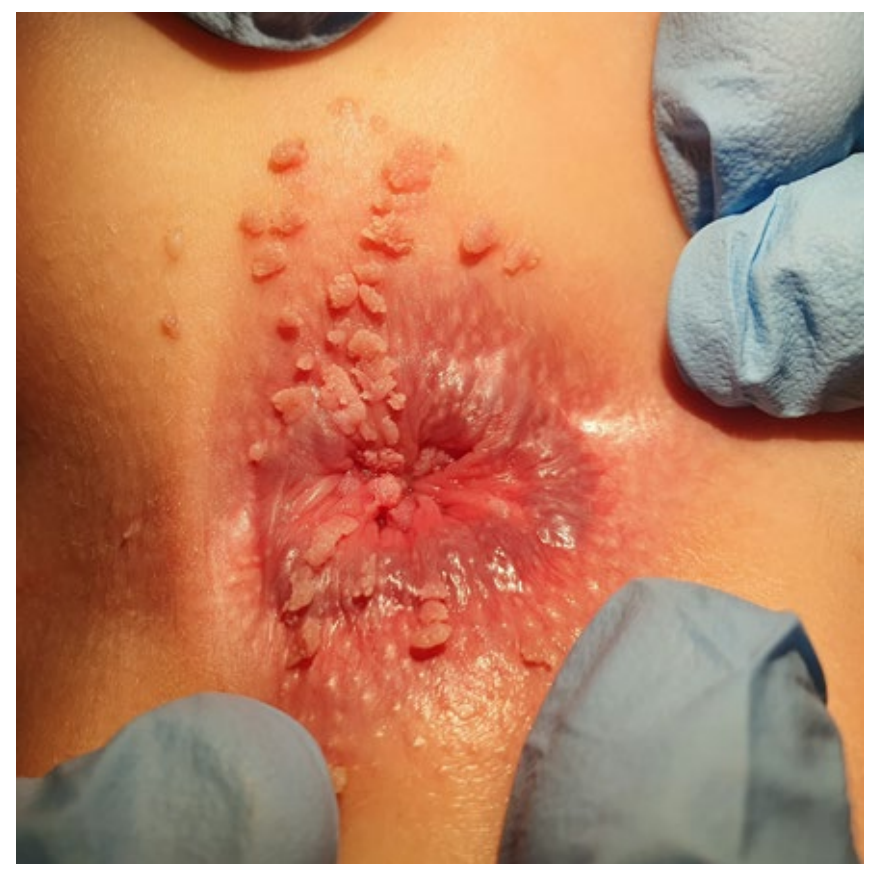

Figure 2 - Extension of the anogenital warts to the anal mucosa.

Active HPV infection on caregivers was excluded and past-treated or untreated infection denied. Multidisciplinary evaluation, with psychological and social assessment, was done and the case reported to the family and criminal court. The child was successfully treated with 8 cycles of weekly applications of topic nitric-zinc complex (Verrutop $\left.{ }^{\circledR}\right)$, with resolution of both anal and perianal lesions. No recurrence has been observed after two months of follow-up.

Human papilloma viruses (HPV) are common pathogens associated with a wide range of cutaneous and mucosal infections in childhood, but anogenital warts are rare. ${ }^{1}$ Transmission can occur sexually but also through non-sexual routes such as perinatal (frequent in children up to 24 months) and direct physical contact 
(usually cutaneous serotypes)., ${ }^{2,3}$ The virus infects primarily epithelial cells through abrasion of the skin or the mucosa, where it can persist as a long-term latent infection (possibly years) until becoming apparent. ${ }^{1,3}$ Also, it can be transmitted by asymptomatic patients. ${ }^{2}$ In most individuals, HPV infection remains transient and asymptomatic, resolving within 2 years. Several factors are thought to play a role in the progression of HPV infection, including individual susceptibility, immune status and nutrition.' Symptomatic children and those with persistent infection should be actively treated. Most treatment strategies studies were conducted in adult populations and its efficacy extrapolated to the pediatric population. ${ }^{2}$ Treatments include topical chemicals/drugs, excisional surgery, cryosurgery, electrosurgery and laser surgery. Nitric-zinc complex is a new topically applied solution containing nitric acid, zinc, copper and organic acids. It has been recently demonstrated to induce a painless caustic effect on "difficult-to-treat warts", including anogenital warts, being effective and well tolerated on adults ${ }^{4}$ and, therefore, a probably good option for children's treatment, as seen in our case. Anogenital warts represent an issue with legal and clinical implications and the possibility of sexual abuse should be considered in all cases. ${ }^{1-3,5}$

\section{Agradecimentos / Acknowledgements}

The authors are grateful for the collaboration of Dra. Cristina Tapadinhas, from the Pediatric Dermatology Department of Centro Hospitalar Lisboa-Norte

Conflicts of Interest: The authors have no conflicts of interest to declare. Financing Support: This work has not received any contribution, grant or scholarship. Confidentiality of Data: The authors declare that they have followed the protocols of their work center on the publication of data from patients. Patient Consent: Consent for publication was obtained. Provenance and Peer Review: Not commissioned; externally peer reviewed.
Conflitos de Interesse: Os autores declaram a inexistência de conflitos de interesse na realização do presente trabalho. Suporte Financeiro: Não existiram fontes externas de financiamento para a realização deste artigo. Confidencialidade dos Dados: Os autores declaram ter seguido os protocolos da sua instituição acerca da publicação dos dados de doentes. Consentimento: Consentimento do doente para publicação obtido. Proveniência e Revisão por Pares: Não comissionado; revisão externa por pares.

\section{ORCID}

Maria São Pedro: https://orcid.org/0000-0002-2032-7460

Tânia C. Pessoa: https://orcid.org/0000-0002-8267-5313

Paula Mourato: https://orcid.org/0000-0002-3108-7167

Susana Correia: https://orcid.org/0000-0003-1116-381X

Corresponding Author: Maria São Pedro

Adress: Av. Movimento das Forças Armadas 79C, 2830-003 Barreiro

E-mail:mia.sps@gmail.com

(c) Author(s) (or their employer(s)) 2021 SPDV Journal. Re-use permitted under CC BY-NC. No commercial re-use.

(c) Autor (es) (ou seu (s) empregador (es)) 2021 Revista SPDV. Reutilização

permitida de acordo com CC BY-NC. Nenhuma reutilização comercial.

\section{REFERENCES}

1. Mammas IN, Sourvinos G, Spandidos DA. Human papilloma virus (HPV) infection in children and adolescents. Eur J Pediatr. 2009; 168:267-73.

2. Costa-Silva M, Fernandes I, Rodrigues AG, Lisboa C. Anogenital warts in pediatric population. An Bras Dermatol. 2017;92:675-81. doi: 10.1590/abd1806-4841.201756411.

3. Armstrong DKB, Handley JM. Anogenital warts in prepubertal children: pathogenesis, HPV typing and management. Int J STD AIDS. 1997; 8:78-81

4. Ciccarese G, Drago F, Granger C, Parodi A. Efficacy assessment of a topically applied nitric-zinc complex solution for the treatment of external anogenital warts in 100 patients. Dermatol Ther. 2019; 9:327-35. doi: 10.1007/s13555-019-0300-7.

5. Kellogg N, American Academy of Pediatrics Committee on Child Abuse and Neglect. The evaluation of sexual abuse in children. Pediatrics. 2005;116:506-512 